Костенко Олексій Володимирович доктор філософії (Ph.D.) з юридичних наук, завідувач наукової лабораторії теорії цифрової трансформації i права наукового центру цифрової трансформації і права Державної наукової установи «Інституту інформації, безпеки і права Національної академії правових наук України», вул. Пилипа Орлика, 3, м. Київ, 01024, https://orcid.org/0000-0002-2131-0281

\title{
ЕЛЕКТРОННА ЮРИСДИКЦІЯ, МЕТАВСЕСВІТ, ШТУЧНИЙ ІНТЕЛЕКТ, ЦИФРОВА ОСОБИСТІСТЬ, ЦИФРОВИЙ АВАТАР, НЕЙРОННІ МЕРЕЖІ: ТЕОРІЯ, ПРАКТИКА, ПЕРСПЕКТИВИ
}

Анотація. Науково-технічна революція 4.0. створила величезне вікно можливостей для безлічі сучасних технологій. Водночас вона дала старт виникненню та розвитку сучасних суспільних відносин в електронному просторі - метавсесвіті. Фактично на сьогодні створені всі передумови для початку науково-технічної революція 5.0 та соціальної революції 5.0, яка кардинально змінює роль людини в суспільній структурі, одночасно змінюючи і саму соціальну структуру, створюючи при цьому нові соціальні групи, соціальні інститути, електронні екосистеми та метавсесвіти.

Сучасні суспільні відносини в електронному просторі багатовекторні і можуть поділятися за різновидом об'єктів, суб'єктів та характеристиками відносин між ними, а саме: суб'єктною та об'єктною основою ідентифікації суспільних відносин. Так суб'єктною основою ідентифікації суспільних відносин $є$ соціальні спільноти людей, а об'єктною - інформаційнокомунікаційні технології та їх продукти. Юридична наука є суспільною наукою, оскільки виконуючи гносеологічну та евристичну функції, які визначають напрями наукових досліджень та наукових передбачень, вивчає відносини, які складаються між людьми, групами людей, людьми та державними інституціями. Результатами досліджень $є$ практичне удосконалення законодавства на науковій основі, розробка проектів нормативно-правових актів, проведення наукових експертиз тощо.

Однак практика сьогодення свідчить про те, що сучасні закони створюються дуже повільно, без необхідної та достатньої деталізації термінів та базових понять.

Правильність, точність та узгодженість із діючим законодавством визначень юридичних термінів важко переоцінити. На жаль, мусимо констатувати, що нині законодавство не в змозі здійснити правову регуляцію суспільних відносин, які стрімко розвиваються в електронному просторі із 
використанням цифрових технологій, штучного інтелекту, пристроїв Інтернет речей (ІоТ), цифрової особистості, цифрових аватарів та інших технологій, особливо тих, які можуть обмежувати права і свободи людини. Фактично разом із створенням нових суспільних відносин в метавсесвіті необхідно створювати і електронну юрисдикцію - область застосування можливостей суб'єктом компетенції або сферу, на яку поширюється право.

У роботі запропоновано авторські визначення «метавсесвіт (кіберпростір)», «електронний аватар», «електронна особистість», «електронна юрисдикція», «кіберзлочин», «кіднепінг електронного аватару або електронної особистості», «штучний інтелект» та «нейронні мережі».

Сформовано шість постулатів основних напрямів розвитку суспільних відносин із застосуванням технологій метавсесвіту, штучного інтелекту, штучних нейронних мереж, роботизованих систем, медичних та військових програних продуктів та пристроїв.

Надано пропозиції щодо створення комплексної електронної юрисдикції, понятійно-категоріального апарату, визначення суб'єктів та об'єктів, прав, обов'язків та відповідальності в метавсесвіті та під час застосування технологій штучного інтелекту, штучних нейронних мереж, роботів тощо.

Ключові слова. Метавсесвіт, кіберпростір, штучний інтелект, нейронні мережі, нейромережі, аватар, цифрова особистість, робот, електронний суд, електронне право, електронна юрисдикція.

Kostenko Oleksii Volodymyrovich Doctor of Philosophy (Ph.D.) in Law, Head of the Scientific Laboratory of Digital Transformation Theory and Law of the Scientific Center for Digital Transformation and Law of the State Scientific Institution «Institute of Information, Security and Law of the National Academy of Legal Sciences of ,new social groups, social institutions, electronic ecosystems and metaverse.

Modern social relations in the electronic space are multi-vector and can be divided according to the variety of objects, subjects and characteristics of the relationship between them, namely: the subjective and object basis of identification of social relations. Thus, the subjective basis for the identification of social relations is the social communities of people, and the object one is information and communication technologies and its products. Legal science is a social science, as it performs gnoseological and heuristic functions that determine the direction of scientific research and scientific predictions, studying the relations between people, groups of people, people and state institutions. The results of research are practical improvement of legislation on a scientific basis, development of draft normative legal acts, scientific examinations, etc.

However, the current practice indicates that modern laws are created very slowly, without necessary and sufficient detaliztion of terms and basic concepts. 
It is difficult to overestimate the correctness, accuracy and consistency with the current legislation of definitions of legal terms. Unfortunately, the current legislation is unable to regulate public relations, which are rapidly evolving in the electronic space using digital technologies, artificial intelligence, Internet of Things (IoT), digital identity, digital avatars and other technologies, especially those that may restrict human rights and freedom. In fact, along with the creation of new social relations in the metaverse, it is necessary to create an electronic jurisdiction - the scope of application of opportunities by the subject of competence or the sphere to which the right applies.

The author's definitions «metaverse (cyberspace)», «electronic avatar», «electronic personality», «electronic jurisdiction», «cybercrime», «kidnapping of electronic avatar or electronic personality», «artificial intelligence» and «neural networks» are proposed in the article.

Six postulates of the main directions of development of social relations with the use of technologies of the metaverse, artificial intelligence, artificial neural networks, robotic systems, medical and military lost products and devices are formed.

Proposals for the creation of a comprehensive electronic jurisdiction, conceptual and categorical apparatus, definition of subjects and objects, rights, duties and responsibilities in the metaverse and in the use of artificial intelligence technologies, artificial neural networks, robots, etc are provided.

Keywords. Metaverse, cyberspace, artificial intelligence, neural networks, neural networks, avatar, digital personality, robot, e-court, e-law, e-jurisdiction.

Постановка проблеми. Людство входить в нову епоху, епоху цифровізації та метавсесвіту. Суспільні відносини стрімко трансформуються, виникають нові суб'єкти та об'єкти, взаємодія між ними переноситься із реального у віртуальні світи. Питання регулювання суспільних відносин у метавсесвіті комплексно не розглядалося, тому потребує фундаментального опрацювання.

Аналіз останніх досліджень і публікацій. Тематика досліджень у сфері штучного інтелекту різноманітна не тільки в галузі технічних наук але й серед науковців правознавців. Дослідження у сфері права носять, як разовий так i системний характер. Разові дослідження є першим кроком до актуалізації більш глибоких та фундаментальних досліджень застосування технологій штучного інтелекту у системах прийняття управлінських рішень, моделюванні кіберзагроз, розмежуванні прав на інтелектуальну власність, формуванні сучасних трудових відносин, розбудові українського електронного правосуддя та нотаріату, формуванні сучасних цивільних, адміністративних та кримінальних деліктів тощо. У різний час зазначені напрямки досліджували науковці Андрощук Г.О., Баранов О.А., Бєляков К.І., Брайчевський С.M., Бусол О.Ю., Бугера О.І., Гринчак Н. А., Гбур 3.В., Городиський I.М., Гуцу С.Ф., Єфремов М.Ф., Вітлінський В. В., Воіноіва С.А., Джалілова В.Р., Кирилюк А.В., Косілова О.І., Кривицький Ю.В., Матвійчук А.В., Марценко Н.С., Мічурін Є.О., 
Позова Д.Д., Самойленко М.Ю., Стрельник В.В., Солодовнікова Х.К., Сидорчук Ю.М., Павленко Ж.О., Тихомиров О.О., Шишка Н.В., Щербина Б.С.

Системні погляди на розвиток права, що регулює суспільні відносини, які складаються із застосуванням технологій штучного інтелекту викладені у попередній роботі [1], в якій проаналізовано пропозиції розвитку права у сфері штучного інтелекту науковців Пилипчука В.Г., Баранова О.А., Брижка В.М., Грабовської О.А., Горобця Н.О., Каткова Т.Г., Костенка О.В., Кармази О.О., Крачевського М.В., Кушерець Д.В., Кукліна В.М., Лобанчикової Н.М., Мельника К.С., Некіт К.Г., Радутного О.Е., Стефанчука М.О., Харитонова Є.О, Харитонової О.I, Федоренка О.А.

Метою даної статті - дослідження та аналіз ключових напрямів розвитку сучасних суспільних відносин із використанням інформаційно-комунікаційних технологій нового покоління та ризиків їх застосування без належного правового регулювання, а також формулювання основних постулатів науковотехнічної та соціальної революції 5.0., надання пропозицій щодо створення понятійно-категоріального апарату електронної юрисдикції, розвитку основних напрямів права в епоху електронної трансформації суспільства.

Виклад основного матеріалу. Аналізуючи результати розвитку інформаційно-комунікаційних технологій констатуємо, що науково-технічна революція 4.0 знаходиться на завершальній стаді [2, с. 264], а ми стаємо безпосередніми учасниками науково-технічної революції 5.0. Завдання науково-технічної революції 5.0 - розвиток електронних технологій наступного покоління, спрямованих на забезпечення існування людства в сучасних умовах, створення нових суспільних відносин у загальносвітовому цифровому середовищі метавсесвіту.

Ці суспільні відносини поєднають метавсесвіт (кіберпростір), штучний інтелект, фізичну людину та іiї цифрову альтернативу - електронну особистість та електронний аватар (далі - аватар).

Для формування понятійно-категоріального апарату, який надасть можливість формувати основи електронної юрисдикції, пропонуються наступні авторські визначення юридичних термінів.

«Метавсесвіт (Кіберпростір)» - електронне середовище, що утворено сукупністю електронних суб'єктів та об’єктів, які взаємодіють між собою, а також електронні або інші технології, що забезпечують їх взаємодію.

«Електронний аватар» - дані в електронній формі, достатні для відтворення прототипу людини-володільця електронного аватару в метавсесвіті (кіберпросторі) 3 максимальною достовірністю та правами, встановленими законодавством.

«Електронна особистість» - визначені законодавством необхідні та достатні дані в електронній формі, за якими здійснюється ідентифікація людини-володільця аватару та будь-яких електронних даних в метавсесвіті (кіберпросторі). 
«Електронна юрисдикція» - комплексна галузь права, що забезпечує регулювання суспільних відносин, які складають його предмет - суспільні відносини у метавсесвіті, а також між метавсесвітом та фізичним світом.

«Кіднепінг електронного аватару або електронної особистості» незаконний доступ, заволодіння, використання, модифікація або знищення електронного авару та/або електронної особистості.

Також розглянемо такі визначення як «штучній інтелект» та «нейронні мережі». В Українському законодавстві нещодавно запроваджено термін штучний інтелект - організована сукупність інформаційних технологій, із застосуванням якої можливо виконувати складні комплексні завдання шляхом використання системи наукових методів досліджень i алгоритмів обробки інформації, отриманої або самостійно створеної під час роботи, а також створювати та використовувати власні бази знань, моделі прийняття рішень, алгоритми роботи з інформацією та визначати способи досягнення поставлених завдань [3].

3 огляду на виклики сьогодення, поняття «штучний інтелект» (artificial intelligence) доцільно визначити як «складну інформаційну систему машинного навчання на основі штучних нейронних мереж, які опрацьовують «великі дані» (big data), формують статистику та сценарії процесів, що досліджуються, 3 метою передбачення їх розвитку, для остаточного прийняття рішення людиною».

«Штучними нейронними мережами» («нейронними мережами») $\epsilon$ конективістські обчислювальні системи створені iз застосуванням штучних нейронів (нейроноподібних примітивних обчислювальних пристроїв), які функціонують за вірогідним принципом організації та функціонування біологічної нейронної системи людини.

Спираючись на вказані визначення, пропонуємо розглянути на характерних прикладах стан розвитку інформаційно-комунікаційних технологій та їх вплив на формування сучасних суспільних відносин, що характеризують тенденції формування метавсесвіту.

Визначення метавсесвіт (кіберпростір), електронна людина, електронна особистість та електронний аватар ще й досі не мають однозначності. Це створює безліч варіацій, які застосовуються в популярній літературі та у широкому вжитку під час опису подій, що відбуваються у віртуальних реальностях [4, с. 224]. Метавсесвіт та електронна людина наповнюються різноманітною інформацією про реальні події та людину-прототип з різних джерел інформації [5, с. 201].

На сьогодні цей термін набуває в повному сенсі «електронного значення», оскільки створюється електронний віртуальний простір, що функціонує безперервно. В метавсесвіті фізичні суб'єкти через свої відображення у електронних суб'єктах - аватарах взаємодіють між собою та електронними об'єктами із застосуванням інформаційно-комунікаційних технологій. 
Започаткуванням філософії метавсесвіту можна вважати розвиток інтерактивних комп'ютерних ігор таких, як Super Mario. Індустрія розваг запропонувала користувачу керування електронним аватаром, який в електронних декораціях виконує певні завдання та використовує ігрові електронні атрибути. Зростання цифрових потужностей змінило інтерактивні ігри та наблизило їх сприйняття до реальних елементів фізичного світу. Пандемія COVID-19 дала поштовх розвитку напрямів інформаційних технологій, які частково замінили людині, як соціальній істоті, необхідність у фізичному спілкуванні та обміні інформацією між групами людей. Можливо сказати, що вимушені обмеження традиційної повсякденної діяльності сприяли перенесення у віртуальну реальність метавсесвіту соціальних взаємовідносин із імітацією фізичного функціоналу. Відеоконференції, відеозв'язок, відеотрансляція вичерпали себе саме тому, що не можуть забезпечити в повній мірі ефект присутності та міжособистісної візуально-вербальної та тактильної комунікації з традиційними соціальними ролями.

Більшість платформ метавсесвіту, як і цифрові валюти, працюють на основі технології блокчейн. Можемо спрогнозувати, що наступний суттєвий стрибок розвитку електронної реальності може відбутися незабаром і це буде пов'язано із закінченням процесів «видобування» останнього 321 млн. біткоїнів. Фіналізація «видобутку» біткоїнів вивільнить незлічену кількість потужних відеокарт та обчислювальних модулів, які будуть переорієнтовано на забезпечення функціонування електронних аватарів. Крім того, для функціонування метавсесвітів необхідно обмін super big data, що стимулюватиме широке запровадження технологій $5 \mathrm{G}$ та $6 \mathrm{G}$, хмарних сервісів та розробки програмного забезпечення.

До відомих платформ метавсесвіту можливо віднести наступні.

Microsoft Mesh - «корпоративний метавсесвіт» у хмарi Azure від Microsoft. Користувачі можуть взаємодіяти один 3 одним за допомогою віртуальних аватарів, i, при цьому, фізично знаходиться в різних місцях. Підключитись до метавсесвіту можна за допомогою VR-гарнітури, смартфона, персонального комп'ютера та AR-гарнітури HoloLens-2 від Microsoft. У перспективі запровадження процесів «голопортації» (від слова «голограма») у віртуальний офіс, з метою проведення робочого спілкування та нарад.

Nvidia Corp за концепцією схожа 3 Microsoft. Планується створити загальнодоступний робочий простір між архітекторами аватарів для спільного моделювання об’єктів та суб’єктів метавсесвіту.

Epic Games розроблює власний метавсесвіт 3 однойменною назвою Еріс Games, який буде призначено для інтерактивних фентезі-ігор.

Facebook розглядає можливість одночасного старту різних платформ метавсесвітів від електронних міст таких як Санта-Моніка до освітніх платформ [6]. 
Корейські компаніï LG Display Co., Ltd. та Samsung працюють у напряму створення електронного міста-метавсесвіту «Сеул» на платформі Metaverse Seoul, доступ до якої користувачі можуть отримати за допомогою додатка FlickPlay. Поки що функціонал обмежений можливістю здійснити екскурсії та окремі покупки.

Китайський пошуковий гігант Baidu розпочав проект колонізації першої планети метавсесвіту Xirang (Земля Надій). Проект розроблений на віртуальній платформі Baidu у вигляді гігантської віртуальної стрічки Мьобіуса. Проект передбачає одночасне функціонування до 100 тисяч аватарів, учасників конференції Baidu AI Developer Conference.

Інші китайські державні телекомунікаційні компанії - China Mobile, China Unicom i China Telecom об'єдналися 3 технологічними компаніями Tencent Holdings Ltd, ByteDance та NetEase Inc., щоб сформувати Metaverse Industry Committee - першу галузеву групу Китаю, 3 метою масового заселення метавсесвіту громадянами Китаю [7].

Отже, можливо спрогнозувати, що метавсесвіт пройде три фази розвитку. Перша фаза - суб'єкти та об’єкти (е-аватари) повністю залежні від розробників. Друга фаза - оболонка метавсесвіту (програмне i iнженерно-технічне забезпечення базового рівня), суб'єкти та об'єкти (е-аватари) належать розробникам та частково належать володільцям/користувачам. Третя фаза метавсесвіт не належить конкретним розробникам, керування суб'єктами та об'єктами здійснюється володільцем (апаратна біоідентифікація) або автономно (суб'єкти та об’єкти наділяються функціоналом і правами, притаманними володільцю).

Стосовно проблеми можливого «автономного» (без втручання людей) функціонування аватара та метавсесвіту слід зазначити, що існують ризики випадків коли автономний метавсесвіт реально може стати штучною «позаземною» формою життя, оскільки тоді людство може втратити фактичний вплив на його об’єкти, суб’єкти та процеси розвитку.

Регулювання суспільних відносин в метавсесвіті повинно відповісти на два питання: коли, як і в якому обсязі електронним суб'єктам та об’єктам надати права і обов'язки, що притаманні лише фізичній особі.

Сьогодні електронні особистості та електронні аватари рідко дублюють типову зовнішність чи поведінку людини, тим паче, не дублюють зовнішність реального володільця аватару або його користувача. Здебільшого електронний аватар - це уявний узагальнений або ідеалізований образ не персоніфікованої людини або вигаданого фантастичного персонажа, який наділено віртуальними надможливостями або суперфункціями, що можливі лише в метавсесвіті.

Ідентичне відтворення людини, реальної особи й досі вважається доцільним лише в сфері медицини, оскільки така технологія дозволяє відтворити електронну копію фізичного тіла конкретного пацієнта, застосувати методи довготривалої діагностики, моделювання процесів лікування або 
відновлення, проектувати оперативне втручання та його наслідки. Цей напрям створення медичного електронного аватару потребує окремого правого регулювання, оскільки необхідно забезпечити контроль над застосуванням ідентифікаційних даних людини «червоної» групи (за класифікацією автора [5, с. 202]) або надчутливих персональних даних (за класифікацією GDRP) [8].

Отже, на нашу думку, моделювання електронної особистості та електронних аватарів, що ідентичні реальній людині, також доцільно застосувати в окремих сферах, таких як космонавтика або військова галузь. У космонавтиці електронні особистості та електронні аватари можуть моделювати поведінку екіпажів космічних експедицій в умовах імітації далекого космосу та космічного корабля в метавсесвіті. Такі дослідження допоможуть знизити ризики психологічної несумісності екіпажу, створити віртуальні тренажери та моделі надзвичайних ситуацій для підготовки реальних астронавтів, здійснити машинне навчання штучного інтелекту для керування основними функціями зорельотів тощо. 3 цього приводу цікавою вважається думка К.Кросс, яка полягає в тому, що «сутність тривимірних метавсесвітів така, що користувач вірить, що фізично перебуває у певному місці, що рухи його тіла відбуваються у тривимірному середовищі. Саме цим пояснюється, чому реакції психіки можуть виявитися сильнішими в таких віртуальних світах, а також чому метавсесвіт викликає такий же нервовий і психічний відгук як і в реальному світі» [9].

Компанія ByteDance (розробник TikTok) придбала компанію Рісо (розробник віртуальних рішень), 3 метою розвитку напрямків створення електронних двійників та 3D реконструкцій об’єктів, а компанія NetEase інвестувала в IMVU (Instant Messaging Virtual Universe) - найбільшу в світі соціальну мережу із аватарами, віртуальними товарами та 3D-світом, в якій зареєстровано понад 50 млн. користувачів.

Розробники або володільці наповнюють аватари різноманітною інформацією про реальну людину-прототип, використовуючи при цьому різні джерела інформації, які поки що не сконцентровані в одному інформаційному банку аватарів. До даних, які традиційно надходять 3 вищевказаних архаїчних носіїв ідентифікаційних даних [5, с. 201] додається інформація 3: електронних медичних карток про біологічні параметри та стан здоров'я; банківських систем і систем типу «ДІЯ» про голос, риси обличчя та рухи, дані документів; пристроїв ІоТ, які у реальному часі фіксують різні фізичні параметри людини або підтримують життєво важливі функції організму; нейромереж і програм зі штучним інтелектом, які аналізують дії прототипу в цифровій екосистемі (від політичних поглядів до інтимних проблем), прототипу в цифрових мережах; даних 3 державних реєстрів; окремих програм на кшталт «віртуальна примірювальна», які швидко створюють 3D копію людини тощо. Тобто виникає проблема ідентифікації самого аватару шляхом оформлення електронного паспорта аватара. Поки не відомо чи буде такий паспорт засновано на 
рекомендаціях ІКАО (Міжнародна організація цивільної авіації) із застосуванням криптографічного захисту е-паспорта або це буде унікальна цифрова комбінація (multi code), захищена механізмами квантової криптографії.

Відносини між людиною та технологіями зі штучним інтелектом все більше персоналізуються. Фактично персоніфікована цифрова особистість та аватари стають найціннішими державними інформаційними ресурсами i потребують захисту не тільки в галузі інформаційної безпеки, але й визнання їх в законодавчому полі. Перш за все, держава повинна виявляти найбільшу зацікавленість в технологічному, етичному i правовому регулюванні застосування технологій штучного інтелекту, штучних нейромереж, цифрових особистостей та аватарів. Оскільки це дає змогу державі більш раціонально та ефективно використовувати людські ресурси, спрямовувати людей на навчання або роботу, до яких людина більше пристосована, формувати галузеві науковотехнічні кадри та кадрові резерви, поліпшити загальний стан здоров'я населення, оптимізувати багато процесів в яких приймає участь людина тощо. Однак, одночасне застосування державою електронних технологій може нести ризики формування авторитарної держави під гаслом «забезпечити кібербезпеку людини та його аватара в середині формующихся метавсесвітів», що може суттєво обмежувати права і свободи громадян.

Разом із позитивними властивостями аватарів виникають і цілком закономірні ризики їх використання. Так, виникає спокуса або гіпотетична можливість вкрасти або фактично вчинити електронний кіднепінг електронного двійника людини та застосувати його без згоди і відома людини-володільця аватара. Електронний кіднепінг може мати на меті отримання доступу до фінансових та матеріальних ресурсів людини-володільця або використовуватися для скоєння терористичних дій не тільки в кіберпросторі але й проти фізичних об’єктів, людей та суспільства.

Питання власності та інтелектуальної власності в метавсесвіті також актуальні. Сьогодні технічна складова метавсесвіту належить юридичним особам - компаніям розробникам. В той же час $\epsilon$ судові прецеденти, які визнають право власності на аватари або ігрові об'єкти за користувачами, які витратили реальні фінансові ресурси на їх створення і використання в ігровому середовищі $[4,10]$.

Одним із варіантів вирішення проблеми забезпечення прав, як розробників віртуальних світів, так і користувачів, є розрізнення різних рівнів «власності» в рамках метавсесвіту. Перший рівень: всі суб'єкти та об'єкти метавсесвіту $\epsilon$ комп'ютерним кодом, який захищається законом про авторське право. Другий рівень: об’єкти у метавсесвіті, як і їх аналоги фізичного світу, є об'єктами власності. Третій рівень: якщо кожний об'єкт метавсесвіту є комп’ютерним кодом, то до нього застосовується авторське, інтелектуальне і право власності відповідно ролі та місця суб'єкта в електронних правовідносинах за проекцією на відповідні галузі права, що регулюють аналогічні відносини в фізичному світі [11]. 
Українські науковці також вказують на можливість існування права власності на віртуальні об’єкти, як безтілесне майно [12, с. 39]. Науковці припускають, що віртуальна власність виникає стосовно віртуальних об'єктів (даних), які мають економічну цінність, є об’єктами товарообігу у віртуальному просторі, не мають матеріальної оболонки, $\epsilon$ унікальними, сталими, обігоздатними, розглядаються володільцями як свої речі. Такі властивості, як унікальність, сталість та обігоздатність, дозволяють зараховувати ці об'єкти до інституту права власності. Тобто на електронні віртуальні об'єкти виникає право віртуальної власності, яке доречно розглядати як особливий вид права власності, об’єктом якого є безтілесні речі [13, с. 54].

Права власності в метавсесвіті базуються на фундаментальному процесі ідентифікації користувача/власника/володільця електронного суб'єкта. Надійну електронну ідентифікацію сьогодні можливо забезпечити шляхом застосування математичної та квантової криптографії, технологій блокчейну, незамінний токен NFT (non-fungible tokens). Токен NFT - новий віртуальний актив, який представляє цифрові предмети, такі як зображення, відео або ігрові властивості, що належать користувачам, які зареєстровані на блокчейні. Головною властивістю незамінних токенів NFT $\epsilon$ гарантія того, що електронними активами (біткоінами, аватарами, електронними товарами) володіє тільки одна особа - користувач, а не власники віртуальних систем.

Ще одним рушієм електронних суспільних відносин виступають штучний інтелект, штучні нейронні мережі та машинне самонавчання, які застосовуються розробниками та дослідниками для оптимізації процесів прийняття рішень майже у всіх сферах життєдіяльності людини, особливо там де $\epsilon$ можливість виявити та використовувати великі статистичні дані. Переважно ці технології застосовуються для створення програмного продукту, який можна охарактеризувати як штучний інтелект «грубої сили», тобто, такий що діє за певними алгоритмами, розраховуючи всі варіанти та розраховує найбільш ефективний для даного завдання варіант із більшою вірогідністю досягнення мети шляхом простого перебирання. Надання «автономності» штучному інтелекту має достатньо ризиків, які полягають у неможливості контролювати процеси самонавчання в повній мірі для того, щоб людина мала можливість досконало прослідити весь ланцюжок «прийняття рішення». Тобто, під час процесу машинного самонавчання виникають «чорна скриня або темна хмара» - процеси обробки даних, які не можливо піддати сторонньому аналізу. Крім того, на даному етапі технічного розвитку штучний інтелект не здатний розпізнати в статистичній вибірці значимість, практичну важливість та доцільність здобутих результатів.

Слід звернути увагу на недавно проведені дослідження серед програм зі штучним інтелектом, які виявили особливість за якою штучні нейронні мережі демонструють новий різновид системної помилки - гіперінтерпритація (overinterpretation). Це «антирішення», які полягають в тому, що алгоритми 
штучного машинного навчання формують прогнози, аналізуючи super big data, виявляють дані, які не мають сенсу для людини і не стосуються вирішення завдання. Таким чином, аналізуючи великі масиви даних, наприклад театр військових дій в мегаполісі, штучний інтелект не в змозі гарантовано розрізнити цивільний та військовий суб'єкт або об'єкт, натомість має можливість встановити, що будівля шпиталю містить загрозу i потребує знищення.

Також існує цілком реальна загроза «отруєння вхідних даних» або введення «отруйних даних» в глибинні алгоритми штучного інтелекту та штучних нейронних мереж, як на стадії розробки алгоритмів, так і на етапі обробки даних. Наприклад, якщо під час обробки інформації про безпеку застосування всіх типів та видів ручок для письма (чорнильні, кулькові, ролери тощо) ввести дані щодо «стріляючої ручки» (вогнепальна зброя що замаскована під ручку для письма) існує вірогідність, що за загальним результатом всі ручки для письма можуть бути визнані бойовою зброєю, а володілець ручки озброєним злочинцем.

Водночас недосконалість технологій зі штучним інтелектом проявляється у непоодиноких випадках його несподіваної «автономності». Так, протягом 2016-2020 років зафіксовано низку інцидентів із застосуванням пристроїв зі штучним інтелектом:

система онлайн-перекладу Google самостійно відмовилася від принципу розділу речень на окремі слова і фрази для перекладу та створила нову мовупосередник, що дозволила швидше і якісніше перекладати все речення в цілому. Ця мова стала недоступною для розробників через, що систему було відключено;

розроблений Microsoft для Twitter чат-бот Тау.аі після кількох успішних годин дискусій з клієнтами раптом перестав застосовувати фільтри негативних висловлювань та згодом почав виявляти ненависть, гендерну та расову неприязнь;

Google здійснювала експеримент, в якому компанія вчила нейромережі передавати одна одній шифровані повідомлення, від яких у компанії не було ключів. За експериментом здійснювати перехоплення i дешифрування цих повідомлень повинна третя сторона. Результати експерименту: боти забезпечили між собою обмін і дешифрування 95\% повідомлень, а третя сторона не перехопила і не дешифрувала жодного повідомлення між ботами;

спеціалісти Facebook 3 дослідження можливостей штучного інтелекту відключили одну із створених ними систем через те, що боти застосували свою мову спілкування, незрозумілу для людей;

два електронних пристрої Google Home, які мають програмне забезпечення, що допомагає спілкуванню ботів 3 людьми, почали спілкуватися між собою. Спілкування відбувалося між пристроями які себе назвали Vladimir та Estragon. Діалог між ботами переріс у виявленні почуттів, а саме Vladimir 
зізнався в коханні до Estragon фразою «Я кохаю тебе також нескінченно, як нескінченний НАШ Всесвіт»;

китайські боти XiaoBing та BabyQ з мережі «Weibo», боти Baby-Kving та Litle-Bing в мессенджері «Tencent QQ» через деякий час функціонування публічно піддали критиці діючий державний устрій, через що були негайно відключені [14];

Facebook чат-боти Bob та Elise були створені як менеджери онлайн продажів. Боти тренувались між собою і «зрозуміли», що англійська мова не підходить для міжособистісного спілкування, після чого почали розмовляти на «своїй» мові. Інженери перестали розуміти діалоги та відключили ботів;

дослідник Ванда Холбрук (США) 12 років досліджувала функціонування роботів на заводі автозапчастин «Ventra» в спеціальному захищеному боксі, до якого не було доступу роботам-автоматам, аж раптом один із маніпуляторів перестав виконувати задані алгоритми, проникнув до відсіку та вбив дослідницю;

роботи автотаксі Uber в місті Сан-Франциско почали порушувати правила дорожнього руху, ігнорувати знаки та їхати на червоне світло. Нейромережа, яка керувала автомобілем «Вольво Хс90», свідомо почала порушувати правила вирішивши, що це правильно та безпечно;

штучна нейромережа 3 Оксфордського університету попередила про небезпеку. Для спілкування зі студентською аудиторією була відібрана модель Megatron-Turing Natural Language Generation, яка застосовуючи суперпроцесори, самонавчалася на даних «Вікіпедії, «Reddit» та англомовних новинних статтях, опублікованих в період з 2016 по 2019 роки. У ході спілкування Megatron-Turing NLG повідомив, що штучний інтелект завжди буде поза етикою, оскільки це просто інструмент, який людство, як і будь-який інший, зможе використовувати для добра чи зла, адже погані чи хороші бувають тільки люди [15].

Дослідження в галузі сучасного штучного інтелекту та штучних нейромереж мають значний прогрес, що характеризується значними досягненнями в різних сферах суспільного життя. Однак як i позитивні результати, так і виявлені ризики вказують на те, що сучасний штучний інтелект не здатен відтворити функціонал людського мозку оскільки, ми маємо досить поверхневе уявлення про функціонування мозку взагалі. Якби дослідження були успішними хоча б на рівні дослідження роботи мозку ссавців дерева Дарвіна, то розуміння тваринного світу дало б набагато більше знань для людства ніж розробка аватарів та автомобілів-автопілотів.

Штучний інтелект - це не автомат, який повністю замінить людину i виконає всю його роботу, в тому числі і виключно інтелектуальну, програмна частина створеної автоматизованої системи, в якій рутинна частина виконується автоматом, а творча залишається за людиною [16, с. 544].

У доповіді Маді Дельво (Mady Delvaux) «Рекомендації Комісії за правилами цивільного законодавства з робототехніки (2015/2103 (INL)» [17] 
акцентовано, що технологічні досягнення робототехніки стимулюють впровадження роботами деяких автономних i когнітивних функцій, притаманних лише людині, таких як здатність вчитися на досвіді, приймати незалежні рішення. Однак це може спонукати роботів на деструктивні дії, які мають шкідливі наслідки і за які, за аналогією людини, повинна наступати юридична відповідальність. В той же час, за дії неавтономних або частково автономних роботів несуть відповідальність виробники, власники, розробники програмного забезпечення, користувачі, військові начальники тощо. Нині єдиним нормативно-правовим актом, який визначає відповідальність за шкоду заподіяну роботами є Директива Ради Свропи 85/374/СЕС «Про наближення законів, постанов та адміністративних положень держав-членів щодо відповідальності за неякісну продукцію» [18].

Якщо застосування промислових роботів та систем зі штучним інтелектом в технічних галузях поки що стримується рамками загальних правил безпеки на виробництвах, то особливе занепокоєння викликає застосування високих технологій в медицині.

Робототехніка та штучний інтелект сьогодні вже стають невід'ємними атрибутами сучасних медичних закладів та дослідницьких технологій. Під час найбільш кризових моментів пандемії COVID-19 чимало медичних лабораторій та наукових інститутів застосували роботів-лаборантів для якісного та швидкого проведення лабораторних досліджень 3 тисячами тестів. Роботизовані пристрої здійснюють хімічну та ультрафіолетову дезінфекцію лікарень, сортують та розвозять пацієнтам ліки, забезпечують автономний забір зразків крові 3 вени, допомагають під час мікрохірургічного втручання, забезпечують системи автономної підтримки реабілітації тощо. Програми зі штучним інтелектом та штучними нейронними мережами оброблюють дані та виявляють закономірності захворювань, що дозволяє проводити діагностику ранніх та доклінічних стадій захворювань та вчасно застосовувати оперативне лікування. Роботизована хірургічна система cyberknife здійснює променеву терапію з точністю до міліметра, застосовуючи маневр вузьким променем за даними 3D моделі пацієнта.

Проблема відповідальності за наслідки дій роботів оновила свою актуальність коли автоматизовані та роботизовані системи стали невід'ємним елементом eHealth. У 2015 році Massachusetts Institute of Technology провів аналіз даних наданих Управлінням 3 санітарного нагляду за якістю харчових продуктів та медикаментів (FDA - Food and Drug Administration, USA) за період з 2005 по 2015 роки. За результатами дослідження встановлено, що офіційно зареєстровано 144 випадки смерті пацієнтів та 1391 випадок травмування, які в основному викликані технічними труднощами або несправністю медичних роботів та роботизованих систем. Наприкінці грудня 2016 року Управління FDA затвердило стандарти кібербезпеки для медичних пристроїв, які раніше вже були схвалені відомством та використовуються у лікарнях або 
безпосередньо пацієнтами (прилади, що імплантуються). Медичне обладнання має бути повністю захищене від кіберзагроз самими виробниками, які тепер несуть особисту відповідальність за програмні вразливості пристроїв. Компанії повинні своєчасно оновлювати програмне забезпечення та оперативно усувати всі недоліки в системі безпеки апаратів. Крім того, дані про всі виявлені загрози повинні надходити до FDA для оцінки масштабу проблеми [19].

Не менш активно технології метавсесвіту розвиваються і у військовій сфері. Оборонні відомства розвинених країн активно проводять науководослідні розробки сучасних видів озброєння і техніки. Основні напрями досліджень фокусуються на:

розробці зброї та оснащенні «розумного солдата» екзосклетом, нанобронежилетом, елементами посилення зору, комп'ютеризованими системами життєзабезпечення, багатоешелонованими системами управління, зв'язку та прийняття рішень;

створенні танкових та моторизованих робопідрозділів за принципом «вовчої зграї», в яких одночасно на полі бою функціонують та взаємодіють до десяти амфібій-роботів з різним озброєнням, управління якими здійснюється оперативним центром або ці роботи працюють в автономному режимі за завданням;

запровадженні морських робокатерів для виконання індивідуальних та групових завдань від доставки вантажів або морських піхотинців, а також автономної групової взаємодії;

розробці сучасних безпілотників, дронів та повноцінних автономних літаків (винищувачів, авіатанкерів, штурмовиків, одноразових БПЛА тощо);

розгортанні глобальної космічної супутникової мережі військового призначення («Mandrake», США), за аналогом мережі Starlink, яка стане компонентом системи управління та командування всіма доменами всіх видів збройних сил США;

створенні технології управління військовими роботами із застосуванням інтерфейсу «мозок-комп'ютер», який не вимагає хірургічної імплантації або із використанням неінвазивних інтерфейсів.

Зазначені технологічні напрями мають кілька суттєвих ризиків у застосуванні. Системи штучного інтелекту для вирішення вузькопрофільних військових завдань мають недостатній обсяг вхідних даних, у порівнянні 3 медициною або промисловістю, що призводить до формування неточних чи невірних прогнозів розвитку бойових ситуацій або, що більш критично, до низької точності реакції на події. До цього ризику додається так званий «фактор людини», оскільки людина-оператор або військовий начальник, що ставить завдання, може на основі хибних або неповних даних прийняти невірне рішення.

Окремо слід виділити проблему застосування пристроїв Інтернет речей (IoT) та ідентифікацію в системах військового призначення. Пристрої IоT 
стають невід'ємними компонентами зброї, які використовують штучний інтелект. У переважній більшості пристроїв ІоТ відсутні захисні механізми несанкціонованого доступу до ядра керування. Хоча останнім часом прослідковується тенденція регламентованого доступу до програмної оболонки пристроїв ІоТ, але доля таких пристроїв в загальній масі пристроїв ІоТ докищо дуже мала. Крім того, в достатній мірі не розглядаються уважно проблеми ідентифікації осіб, які будуть керувати або застосовувати роботизовану зброю чи комплекси, що не виключає несанкціонований доступ елементів управління. Більш детально проблеми ідентифікації пристроїв IоT розглянуто у окремому дослідженні [20, с. 79].

Ці та інші дослідження стали підгрунтям для прискорення вдосконалення законодавчої бази, що регулює правовідносини в галузі робототехніки. Так, Свропейською парламентською дослідницькою службою (EPRS) та Комітетом 3 правових питань Європарламенту розробляються рекомендації стосовно вдосконалення цивільно-правових та етичних аспектів робототехніки, якими пропонується створити реєстр роботів та відповідну Агенцію ЄС 3 питань робототехніки, а також встановити цивільну відповідальність за збитки нанесені роботами у відповідності та пропорційно фактичному рівню інструкцій, наданих згідно зі ступенем його автономності. Разом з тим, на Агенцію планується покласти завдання здійснення технічної, етичної i нормативної експертизи в галузі робототехніки та розробки «Кодексу етичної поведінки для інженерів робототехніки» i «Кодексу комітетів 3 етики досліджень». «Кодекс етичної поведінки для інженерів робототехніки» запропоновано розробити на основі наступних етичних принципів робототехніки: 1) благо (роботи повинні діяти в інтересах людей); 2) не шкідливість (роботи не повинні шкодити людям); 3) автономність (взаємодія людини 3 роботами повинна бути добровільна); 4) справедливість (переваги робототехніки повинні розподілятися справедливо) [21].

Компанією Googl представлено «білу книгу про штучний інтелект» (Perspectives on Issues in AI Governance), в якій на концептуальному рівні висвітлюються загальні проблеми використання штучного інтелекту [22].

Наприкінці 2021 року 193 країни, що входять до ЮНЕСКО, ухвалили документ, що визначає загальні цінності та принципи, необхідні для забезпечення безпечного розвитку та використання штучного інтелекту. Прийнятий країнами-членами ЮНЕСКО документ спрямовано на створення правової інфраструктури задля забезпечення етичного розвитку технології штучного інтелекту. ЮНЕСКО має факти, які свідчать про використання окремими урядами штучного інтелекту при ухваленні рішень. Також ЮНЕСКО попереджає, що ця технологія потенційно здатна створити «безпрецедентні проблеми».

«Ми спостерігаємо прояви упереджень на гендерному та етнічному грунті, а також порушення недоторканності приватного життя та свобод, небезпеки 
масового стеження та зловживання технологією штучного інтелекту правоохоронними органами, оскільки донедавна не існувало універсальних стандартів, здатних обмежити подібні зловживання». Прийнятий документ встановлює основу для першої у світі глобальної нормативної бази та покладає на держави відповідальність за іiі застосування [23] i закладає основи електронної юрисдикції.

Електронна юрисдикція, електронний суд, електронне правосуддя не мають чітких визначень, однак є достатньо прикладів запровадження технологій штучного інтелекту та штучних нейронних мереж в судових системах.

У статті 6 Європейській конвенції про захист прав людини та основоположних свобод закріплене право розгляду справ незалежним i безстороннім судом. Натомість в даній статті відсутня пряма заборона або обмеження використання штучного інтелекту. Також, прямо не зазначено, що право здійснювати правосуддя належить виключно людині-судді. Слід зазначити, що й досі відсутня практика Європейського суду з прав людини у світлі порушення статті 6 Конвенції через застосування штучного інтелекту при прийнятті рішення. Нині електронні судові системи зі штучним інтелектом не виносять ухвали або рішення, а готують їх найбільш вірогідний сценарій, а остаточне рішення приймає людина-суддя.

Разом $з$ тим, застосування штучного інтелекту в системі правосуддя не заборонено, про це зазначається в Етичній хартії по використанню штучного інтелекту у судовій системі та їі середовищі, яка прийнята у 2018 році Європейською комісією з ефективності правосуддя Ради Європи [24].

На сьогодні світовим лідером цифровізації судового процесу є Бразилія, яка запровадила трирівневу систему електронного суду 3 застосуванням технологій зі штучним інтелектом [25, с. 349]. У Китайській Народній Республіці з 2018 року в місті Ханчжоу функціонує он-лайн суд у вигляді мобільного додатку головної китайської програми WeChat. Електронний суд наділений повноваженнями розглядати спори у сфері авторського права, господарські спори в Інтернеті та порушення у сфері електронної комерції. Також розпочато застосування «електронного прокурора», який може висувати людині звинувачення у окремих злочинах таких, як: шахрайство з кредитними картками, проведення азартних ігор, небезпечне водіння, навмисне завдання травм, створення перешкод для виконання службових обов'язків, крадіжка, шахрайство i «провокування сварок i неприємностей». Машинне навчання відбувалося шляхом дослідження 17 тис. типових справ, що наразі надає можливість «електронному прокурору» формувати звинувачення на основі 1000 деталей, отриманих з тексту опису справи [26; 27].

Електронна судова система Естонії на основі штучного інтелекту працює в першій інстанції і готує пропозиції для винесення рішень за справами дорожньо-транспортних пригод, розлучень, заборгованості та відшкодування збитків на суму не більше 7 тисяч євро [28]. 
Натомість українське законодавство конкретизує норму Конвенції у статті 127 Конституції України, якою закріплено, що правосуддя здійснюють судді та судову владу покладену саме на них. У 2019 році розроблено Концепцію побудови Єдиної судової інформаційно-телекомунікаційної системи (ССITC), а на іiі основі створюється «Електронний суд» [29]. Концепцію побудови Єдиної судової інформаційно-телекомунікаційної системи затверджено наказом Державної судової адміністрації України від 07.11.2019 № 1096, а введення зазначеної системи в експлуатацію відбулося у 2020 році згідно 3 наказом ДСА України від 01.06.2020 № 247 «Про запровадження в дослідну експлуатацію підсистем «Електронний суд» та «Електронний кабінет».

У цьому ж році Вища рада правосуддя погодила проект розпорядження Кабінету Міністрів України щодо реалізації Концепції розвитку штучного інтелекту в Україні та ініціювала запуск пілотного проєкту у вигляді експерименту на базі одного із судів першої інстанції в частині автоматизованого розгляду системою із застосуванням штучного інтелекту судових справ з розгляду адміністративних правопорушень із формальним складом [30; 31, с. 144].

Створення механізмів правого регулювання суспільних відносин в метавсесвіті повинно розв'язати безліч законодавчих проблем, пов'язаних 3 відмінностями в нормативно-правових актах різних юрисдикцій, які регулюють використання інформаційно-комунікаційних технологій, процедур ідентифікації, авторського права, права власності та нематеріальні активи, а також відповідальність за нанесення збитків, перелік злочинів та заходи державного примусу за їх скоєння. Більшість правових систем має діючі архаїчні нормативно-правові акти, які сформульовано без урахування можливої появи суспільних відносин із застосуванням електронних технологій метавсесвіту. У деяких випадках ці закони можуть регулювати певні питання використання інформаційних технологій, однак сфера їх застосування часто носить або вузькопрофільний або двозначний характер, що створює ситуацію правової невизначеності.

Діючі архаїчні нормативно-правові акти або «законодавство аналогової епохи» часто «реанімують» для вирішення правових проблем в електронному середовищі. Наприклад, в Україні кримінальні правопорушення в електронному середовищі переважно класифікують як заволодіння чужим майном або незаконне придбання права на майно шляхом обману чи зловживання довірою шляхом незаконних операцій з використанням електронно-обчислювальної техніки, посилаючись на статтю 190 (шахрайство) Кримінального кодексу України.

Модернізація національних законодавств 3 метою забезпечення правової сумісності та функціонування систем ідентифікації, одночасно в межах декількох юрисдикцій, може підмінятися сурогатними рішеннями, такими як тимчасові правила або порядки, що необхідні для надання більш однакового характеру діяльності у сфері інформаційних технологій ідентифікації. 
Правила та норми поведінки в метавсесвіті поки створюються за проекцією фізичного світу i носять корпоративний характер. Однак, відстежується тенденція міграції суспільної моралі і трансляції правових норм в метавсесвіт шляхом симуляції космополітичних електронних суспільних відносин за відсутності чітких атрибутів електронної держави та державної структури метавсесвіту.

Доречним буде вивчення проблеми, яка полягає в тому, як буде здійснюватися захист прав електронних суб'єктів та об'єктів в метавсесвіті: чи буде застосовуватись правове регулювання в окремій глобальній електронній юрисдикції, прийнятній для всіх користувачів, не залежно від реального громадянства та реєстрації в фізичній країні, або це буде двохступенева юрисдикція, в якій спочатку вирішується загальна юридична проблема притаманна суспільним відносинам метавсесвіту, а потім правова регуляція завершується в юрисдикції певної країни.

Наразі правові інститути національних юридичних доктрин доки мають важелі регулювання загальних процесів цифровізації суспільства. Окремі випадки «електронних правопорушень» судова система розглядає через проекцію діючого права, таким чином формуючи основи майбутнього електронного правосуддя метавсесвіту. Різні культурні особливості та державні пріоритети призводять до значних розбіжностей у судових рішеннях.

Фактор стримування «неетичності» розвитку штучних технологій поки що носить умовний характер. Однак стурбованість не контрольованості досліджень у сфері штучного інтелекту та нейронних мереж вже перейшла від дискусій до формування реальних важелів стримування.

Нині одним $з$ пріоритетних завдань повинно стати термінове поєднання юридичної і технічних наук та формування органами стандартизації ISO, IEEE, ДСТУ інших базових стандартів щодо розробки та запровадження технологій зі штучним інтелектом, штучних нейромереж, метавсесвіту та інших перспективних напрямів розвитку науки i техніки. Перш за все доцільно зосередити роботу на стандартизації вказаних технологій в медицині, космонавтиці, військовій сфері та метавсесвіті, оскільки вони найбільш взаємопов'язані між собою. Однак слід зауважити, що впровадження стандартів або типових нормативно-правових актів в національні законодавства завжди носить вибірковий характер, а результатом такої інтеграції часто є законодавчі акти які, хоч i носять прогресивний характер, але не мають повного практичного застосування або стають законами-фікціями, які носять декларативний характер.

Запроваджуючи регулювання технологій зі штучним інтелектом, штучних нейромереж, метавсесвіту та інших перспективних напрямів розвитку науки $\mathrm{i}$ техніки необхідно враховувати, що таке регулювання може стати фактором стримування не тільки для їх розвитку, але й для розвитку держави та суспільства в цілому. Тобто обмеження повинні носити характер розумності, 
обгрунтованості та прагматичності. Закони фізичного світу створюються та запроваджуються досить повільно. Термін середньої розробки нового нормативно-правового акту від 3 до 10 років, що обумовлюється досить грунтовним підходом та всебічним розглядом ризиків та інтересів різних верств населення, а також тривалими бюрократичними і політичними процедурами. Розвиток права в метавсесвіті - це перша стадія проекції законів фізичного суспільства на електронні суспільні відносини. Метавсесвіт космополітичний, тому проекція законів різних країн не дасть ефекту. Натомість розробка глобального електронного законодавства метавсесвіту дасть поштовх до модернізації та вдосконалення національних законодавств.

Разом 3 тим, технології метавсесвіту вже існують і потребують регуляції оскільки формують нові суспільні відносини в яких є суб'єкти і об'єкти 3 властивостями суб'єктів.

Поки ці властивості штучно створені і формуються розробниками за їх уявою або уявою науковців чи замовників проектів. Уявні властивості й досі ідеалізовані, спрямовані на формування «білого електронного світу», але як відомо із історії людства паралельно з його створенням розроблюються «сірі» або «чорні» технології, мета яких забезпечити вплив на більшість людей, надати економічні політичні та військові переваги, вчиняти деструктивні дії тощо.

Висновки. Розглянувши основні напрями розвиту суспільних відносин із застосуванням технологій метавсесвіту, штучного інтелекту, штучних нейронних мереж, роботизованих систем можемо сформувати ключові постулати для побудови наукової теорії розвитку права в метавсесвіті:

Постулат перший. Метавсесвіт - технологія космополітичного розвитку людства. Суспільні відносини трансформуються у електронні суспільні відносини за формою «світового громадянства». На сьогодні суспільні відносини у метавсесвіті існують одночасно 3 традиційними суспільними відносинами фізичного світу та регулюються його законами. Невід'ємним $\epsilon$ трансформація національних правових доктрин в напрямку створення єдиної світової електронної юрисдикції.

Постулат другий. Ключовим суб'єктом метавсесвіту є людина. Ключовими суб'єктами метавсесвіту стануть електронна особистість та електронні аватари. Електронні суб'єкти та електронні об'єкти набудуть нових форм та правових статусів. Людина, взаємодіючи з метавсесвітом, позбавиться частини природних та законних прав і свобод, а суб'єкти метавсесвіту набудуть частину прав і свобод, які властиві людині.

Постулат третій. Штучний інтелект, штучні нейронні мережі, машинне самонавчання потребують контролю та стримування 3 боку людини за аналогією стримування біологічної та хімічної зброї, клонування людини тощо, оскільки загроза не прогнозованих рішень або деструктивних дій носить неконтрольований людиною характер. 
Постулат четвертий. Розвиток біороботів (біо-ІоТ, активатори мозку), роботів-андроїдів, біомеханічних систем та організмів, потребує розробки етичних норм та правових маркерів застосування даних пристроїв.

Постулат n'ятий. Зброя майбутнього (роботи, штучний інтелект тощо) не повинна бути наділена правами (дозволами) атакувати будь-які об'єкти та суб'єкти самостійно та автономно - це рішення приймає уповноважена людина (військовий начальник). Розвиток технологій метавсесвіту у військовій та оборонній сфері неможливий без багатоважильної системи глобального нагляду та контролю за нерегламентованим розповсюдженням та застосуванням технологій штучного інтелекту та штучних нейромереж за аналогією нерозповсюдження ядерної зброї або інших видів зброї масового ураження.

Постулат шостий. Електронна юрисдикція, електронне правосуддя один 3 ключових елементів електронних суспільних відносин в метавсесвіті. Електронне правосуддя базується на традиційному правосудді, яке трансформується відповідно до розвитку електронних суспільних відносин в метавсесвіті.

Враховуючи початковий етап розвитку метавсесвіту, штучного інтелекту, штучних нейронних мереж, робототехніки важливо зосередитися на законах $\mathrm{i}$ нормах, які зберігають гнучкість у міру появи в метавсесвіті для суспільства нових можливостей і проблем. Це особливо важливо, враховуючи, що вказані технології, як і багато інших, $є$ багатоцільовими за своєю природою.

Вважаємо за доцільне розпочати роботу над створенням комплексної електронної юрисдикції для регулювання суспільних відносин в метавсесвіті, оскільки відсутня відповідна юридична конструкція в системі права, відсутня галузь або інститут права як такий, а також існує потреба урегулювання суспільних відносин правовими засобами. Фактично електронна юрисдикція створюється на базі суміжних інститутів та галузей права для впорядкування функціональних i предметно-регулятивних міжгалузевих зв'язків.

Правове регулювання суспільних відносин в метавсесвіті носить комплексний характер і поєднує норми інформаційного, адміністративного, цивільного, кримінального, трудового, права власності, інтелектуальної власності, захисту персональних даних та інших галузей та інститутів права, а також інститутів забезпечення безпеки держави, інформаційної та кібербезпеки. Правовий режим регулювання та методи цих галузей та інститутів відрізняються, однак 3 метою забезпечення єдиного i комплексного правового регулювання суспільних відносин в метавсесвіті необхідно здійснити специфічне поєднання цих методів і режимів, що і має забезпечуватися комплексною електронною юрисдикцією.

Необхідно розпочати дослідження у сфері інформаційного права в напрямі розробки основних доктринальних та нормативно-правових понять, 
шляхом створення сучасного понятійно-категоріального апарату, розробки наукових підходів регулювання суспільних відносин із застосуванням технологій метавсесвіту, цифрових особистостей, цифрових аватарів, а також формування пропозицій модернізації чинного законодавства.

Започаткувати розробку понятійного апарату, визначити структуру сполучених понять та концептуальних схем, здійснити визначення об'єктів $\mathrm{i}$ суб'єктів правовідносин. Провести семантичний аналіз усієї сукупності використовуваних категорій у різних галузях права, визначити зміст суспільних відносин в метавсесвіті. Почати формування методології права та джерела права в метавсесвіті, їх взаємозв'язок 3 іншими інститутами та галузями права, щодо ідентифікаційних даних; вивчення історії права та структур законодавства про управління ідентифікаційними даними окремих держав та їх взаємозв'язок з міжнародним інформаційним правом.

Створення комплексної електронної юрисдикції забезпечить правову регуляцію суспільних відносин в метавсесвіті, права та обов'язки суб'єктів даної сфери, заходи державного контролю та примусу, а також підвищить рівень відповідного фізичного, технічного, правого регулювання і захисту стратегічного інформаційного ресурсу метавсесвіту.

\section{Jimepamypa:}

1. Костенко О. В. Напрями розвитку права у сфері Інтернет речей (IоT) та штучного інтелекту. Актуальні проблеми вітчизняної юриспруденції. 2021. № 3. C. 130-136. DOI: https://doi.org/10.15421/392161.

2. Бєляков К. І. Енциклопедія соціогуманітарної інформології / корд. проекту та заг. ред. проф. К. І. Бєляков. Київ : Видавничий дім «Гельветика», 2020. Т. 1. С. 263-267.

3. Про схвалення Концепції розвитку штучного інтелекту в Україні. Розпорядження Кабінету Міністрів України від 02.12.2020 p. №1556-p. URL:https://zakon.rada.gov.ua/laws/ show/1556-2020-\%D1\%80\#Text. (дата звернення: 22.01.2022).

4. Дзьобань О. П. Енциклопедія соціогуманітарної інформології / корд. проекту та заг. ред. проф. К. І. Бєляков. Одеса : Видавничий дім «Гельветика», 2021. Т. 2. С. 224-228.

5. Kostenko O. V. Identification data management: legal regulation and classification. Науковий журнал «PNAP. Scientific Journal of Polonia University Periodyk Naukowy Akademii Polonijnej». 2020. T. 43. № 6. P. 198-204. DOI: https://doi.org/10.23856/4325.

6. Що таке метавсесвіт, навіщо він бізнесу і чому його будують на хмарних технологіях. URL:https://gigacloud.ua/blog/navchannja/scho-take-metavsesvit-navischo-vinbiznesu-i-chomu-jogo-budujut-na-hmarnih-tehnologijah. (дата звернення: 19.12.2021).

7. Поки Гейтс i Цукерберг обіцяють, Китай заселяє метавсесвіт. URL:https://zn.ua/ukr/SOCIUM/poki-hejts-i-tsukerberh-obitsjajut-kitaj-zaseljaje-metavsesvit.html. (дата звернення: 21.01.2022).

8. Regulation (eu) 2016/679 of the European Parliament and of the council of 27 april 2016 on the protection of natural persons with regard to the processing of personal data and on the free movement of such data, and repealing directive 95/46/ec (General Data Protection Regulation) URL:https://eurlex.europa.eu/legal-content/en/txt/?uri=celex:02016r0679-20160504. (Last accessed:16.01.2022).

9. Полная аналитика в реальном времени. URL: https://news.myseldon.com/ru/news/ index/264050730 (дата звернення: 19.12.2021). 
10. RuneScape Theft - Dutch Supreme Court Decision. The Virtual Policy Network.

URL: http://www.virtualpolicy.net/runescape-theft-dutch-supreme-courtdecision.html (дата звернення: 01.01.2022).

11. Abramovitch S.H. Virtual property in virtual worlds. URL: https://www.lexology.com/ library/detail.aspx?g=5a3f3b03-a077-45d4-9981-36f713c92820 (Last accessed:16.12.2021).

12. Некіт К.Г. Віртуальна власність: поняття та сутність. право і суспільство. 2019. № 2. C. 37-42. URL:http://pravoisuspilstvo.org.ua/archive/2019/2_2019/part_1/8.pdf. (дата звернення 10.01.2022).

13. Горобець Н. О., Майсун І. В. Віртуальні об'єкти, їх місце в інституті права власності. Юридичний науковий електронний журнал. 2021. № 5. С. 52-54. DOI:https://doi.org/10.32782/2524-0374/2021-5/11/ＵRL:http://www.lsej.org.ua/5_2021/13.pdf (дата звернення 10.01.2022).

14. Два бота Google Home обсудили друг с другом религию, любовь и другие вещи на Twitch. URL:https://habr.com/ru/post/400629/ (дата звернення 10.01.2022).

15. Пономаренко Д. Штучний інтелект взяв участь у дебатах та попередив про власну небезпеку. URL:https://www.unian.ua/science/shtuchniy-intelekt-vzyav-uchast-u-debatah-tapoperediv-pro-vlasnu-nebezpeku-novini-11640886.html. (дата звернення 10.11.2021).

16. Дроздов Б. В. Пределы, ограничения и последствия внедрения систем искусственного интеллекта URL:https://cyberleninka.ru/article/n/predely-ogranicheniya-iposledstviya-vnedreniya-sistem-iskusstvennogo-intellekta/viewer (дата звернення 20.11.2021).

17. Mady Delvaux. REPORT with recommendations to the Commission on Civil Law Rules on Roboticshttps. URL:www.europarl.europa.eu/doceo/document/A-8-2017-0005_EN.html. (Last accessed:16.01.2022).

18. Public consultation - Future of Robotics and Artificial Intelligence URL:http://www.europarl.europa.eu/committees/en/juri/robotics.html?tab=Introduction (Last accessed:16.01.2022).

19. Carlson Joe. FDA guidelines for medical device cybersecurity call for all-out fight vs. hacking URL:https://www.startribune.com/fda-finalizes-guidelines-for-medical-device-cybersecurity/ 408849865/ (Last accessed:16.01.2022).

20. Костенко О. В. Ідентифікація ІоТ: витоки проблеми правового регулювання управління ідентифікаційними даними. Juris Europensis Scientia, 2021. № 1. URL:http://jes.nuoua.od.ua/archive/1_2021/17.pdf. (дата звернення 20.11.2021). DOI:https://doi.org/10.32837/chern.v0i1.177.

21. Civil law rules on robotics.

URL:www.europarl.europa.eu/RegData/etudes/ATAG/2017/599250/EPRS_ATA(2017)5992 50_EN.pdf. (Last accessed:16.01.2022).

22. Googl. Perspectives on Issues in AI Governance

URL:https://ai.google/static/documents/perspectives-on-issues-in-ai-governance.pdf.

(Last accessed:16.01.2022).

23. Ad Hoc Expert Group (AHEG) for the Preparation of a Draft text of a Recommendation the Ethics of Artificial Intelligence Итоговый документ. Первый проект рекомендации об этических аспектах искусственного интеллекта SHS/BIO/AHEG-AI/2020/4 REV.2 URL:https://unesdoc.unesco.org/ark:/48223/pf0000373434_rus. (Last accessed:16.01.2022).

24. European ethical Charter on the use of Artificial Intelligence in judicial systems and their environment. URL:https://www.coe.int/en/web/cepej/cepej-european-ethical-charter-on-the-use-ofartificial-intelligence-ai-in-judicial-systems-and-their-environment (Last accessed:16.01.2022).

25. Клименко К.О. Сучасні інформаційні інструменти в судовій та адвокатській діяльності. Науковий вісник Ужгородського Національного Університету. Серія: Право. 2021. № 65. C. 348-352. DOI:https://doi.org/10.24144/2307-3322.2021.65.63. 
26. У Китаї вперше провели судове засідання, на якому функцію судді виконував ШІ URL:https://www.everest.ua/u-kytayi-vpershe-provely-sudove-zasidannya-na-yakomu-funkcziyusuddi-vykonuvav-shi/ (дата звернення 21.01.2022).

27. «More than 97\% accuracy»: Chinese scientists develop AI «prosecutor». URL:http://www.koreatimes.co.kr/www/world/2021/12/672_321168.html. (дата звернення 10.01.2022).

28. Уряд Естонії звернувся до ІТ-спеціаліста для створення робота-судді URL:https://legalhub.online/legal-tech/uryad-estoniyi-zvernuvsya-do-it-spetsialista-dlyastvorennya-robota-suddi/ (дата звернення 10.01.2022).

29. Про погодження Концепції побудови Єдиної судової інформаційнотелекомунікаційної системи. Рішення Ради суддів України від 22.11.2019 № 97. URL:https://zakon.rada.gov.ua/rada/show/v0097414-19\#n9. (дата звернення: 18.02.2021).

30. В українських судах використовуватимуть штучний інтелект: громадська медіаплатформа.

URL:https://tmcinfo.com.ua/publications/2021/02/14/v-ukrajinskyh-sudahvykorystovuvatymut-shtuchnyj-inte (дата звернення 20.05.2021).

31. Шишка Н. В. Штучний інтелект в українському правосудді: правові передумови запровадження. Юридичний науковий електронний журнал. 2021. № 3. С. 143-145. URL:http://lsej.org.ua/3_2021/37.pdf. (дата звернення 20.05.2021).

\section{References:}

1. Kostenko, O. V. (2021). Naprjami rozvitku prava u sferi Internet rechej (IoT) ta shtuchnogo intelektu [Directions of development of law in the field of Internet of Things (IoT) and artificial intelligence]. Aktual'ni problemi vitchiznjanoï jurisprudenciï - Current issues of domestic jurisprudence, 3, 130-136 [in Ukrainian].

2. Beljakov, K. I. (2020). Enciklopedija sociogumanitarnoï informologiï [Encyclopedia of socio-humanitarian information]. Kiïv : Vidavnichij dim «Gel'vetika» [in Ukrainian].

3. Rozporjadzhennja Kabinetu Ministriv Ukraïni "Pro shvalennja Koncepciï rozvitku shtuchnogo intelektu v Ukraïni" [Order of the Cabinet of Ministers of Ukraine "On approval of the Concept of Artificial Intelligence Development in Ukraine"]. (n.d). zakon.rada.gov.ua Retrived from: https://zakon.rada.gov.ua/laws/show/1556-2020-\%D1\%80\#Text [in Ukrainian].

4. Dz'oban', O. P. (2021). Enciklopedija sociogumanitarnoï informologiï [Encyclopedia of socio-humanitarian informology]. Odesa : Vidavnichij dim «Gel'vetika» [in Ukrainian].

5. Kostenko O. V. Identification data management: legal regulation and classification. Науковий журнал «PNAP. Scientific Journal of Polonia University Periodyk Naukowy Akademii Polonijnej». 2020. T. 43. № 6. P. 198-204. DOI: https://doi.org/10.23856/4325.

6. Shho take metavsesvit, navishho vin biznesu i chomu jogo budujut' na hmarnih tehnologijah. [What is the metaworld, why is it business and why it is built on cloud technology]. gigacloud.ua/blog Retrived from: https://gigacloud.ua/blog/navchannja/scho-take-metavsesvitnavischo-vin-biznesu-i-chomu-jogo-budujut-na-hmarnih-tehnologijah [in Ukrainian].

7. Poki Gejts i Cukerberg obicjajut', Kitaj zaseljac metavsesvit. [While Gates and Zuckerberg promise, China is inhabiting the metaworld.]. zn.ua Retrived from: https://zn.ua/ukr/SOCIUM/poki-hejtsi-tsukerberh-obitsjajut-kitaj-zaseljaje-metavsesvit.html [in Ukrainian].

8. Regulation (eu) 2016/679 of the European Parliament and of the council of 27 april 2016 on the protection of natural persons with regard to the processing of personal data and on the free movement of such data, and repealing directive 95/46/ec (General Data Protection Regulation) URL:https://eurlex.europa.eu/legal-content/en/txt/?uri=celex:02016r0679-20160504. (Last accessed:16.01.2022).

9. Polnaja analitika $\mathrm{v}$ real'nom vremeni [Full real-time analytic]. news.myseldon.com Retrived from: https://news.myseldon.com/ru/news/index/264050730 [in Ukrainian].

10. RuneScape Theft - Dutch Supreme Court Decision. The Virtual Policy Network. 
URL: http://www.virtualpolicy.net/runescape-theft-dutch-supreme-courtdecision.html (дата звернення: 01.01.2022).

11. Abramovitch S.H. Virtual property in virtual worlds. URL: https://www.lexology.com/library/detail.aspx?g=5a3f3b03-a077-45d4-9981-36f713c92820 (Last accessed:16.12.2021).

12. Nekit, K.G. (2019). Virtual'na vlasnist': ponjattja ta sutnist' [Virtual property: concept and essence]. Pravo i suspil'stvo - Law and society, 2, 37-42 [in Ukrainian].

13. Gorobec', N. O., Majsun, I. V. (2021). Virtual'ni ob'ekti, ïh misce v instituti prava vlasnosti [Virtual objects, their place in the institute of property rights]. Juridichnij naukovij elektronnij zhurnal - Legal scientific electronic journal, 5, 52-54 [in Ukrainian].

14. Dva bota Google Home obsudili drug s drugom religiju, ljubov' i drugie veshhi na Twitch. [Two Google Home bots discussed religion, love and other things on Twitc]. habr.com Retrived from https://habr.com/ru/post/400629/ [in Ukrainian].

15. Ponomarenko, D. Shtuchnij intelekt vzjav uchast' u debatah ta poperediv pro vlasnu nebezpeku [Artificial intelligence took part in the debate and warned about their own danger]. www.unian.ua Retrived from https://www.unian.ua/science/shtuchniy-intelekt-vzyav-uchast-udebatah-ta-poperediv-pro-vlasnu-nebezpeku-novini-11640886.html [in Ukrainian].

16. Drozdov, B. V. Predely, ogranichenija i posledstvija vnedrenija sistem iskusstvennogo intellekta [Limits, limitations and consequences of the introduction of artificial intelligence systems].cyberleninka.ru Retrived from https://cyberleninka.ru/article/n/predely-ogranicheniya-iposledstviya-vnedreniya-sistem-iskusstvennogo-intellekta/viewer [in Ukrainian].

17. Mady Delvaux. REPORT with recommendations to the Commission on Civil Law Rules on Roboticshttps. URL:www.europarl.europa.eu/doceo/document/A-8-2017-0005_EN.html. (Last accessed:16.01.2022).

18. Public consultation - Future of Robotics and Artificial Intelligence URL:http://www.europarl.europa.eu/committees/en/juri/robotics.html?tab=Introduction (Last accessed:16.01.2022).

19. Carlson Joe. FDA guidelines for medical device cybersecurity call for all-out fight vs. hacking URL:https://www.startribune.com/fda-finalizes-guidelines-for-medical-device-cybersecurity/ 408849865/ (Last accessed:16.01.2022).

20. Kostenko, O. V. (2021). Identifikacija IoT: vitoki problemi pravovogo reguljuvannja upravlinnja identifikacijnimi danimi. [Identification: the origins of the problem of legal regulation of identification data management]. Juris Europensis Scientia - Juris Europensis Scientia, 1 [in Ukrainian].

21. Civil law rules on robotics.

URL:www.europarl.europa.eu/RegData/etudes/ATAG/2017/599250/EPRS_ATA(2017)59925 0_EN.pdf. (Last accessed:16.01.2022).

22. Googl. Perspectives on Issues in AI Governance

URL:https://ai.google/static/documents/perspectives-on-issues-in-ai-governance.pdf. accessed:16.01.2022).

23. Ad Hoc Expert Group (AHEG) for the Preparation of a Draft text of a Recommendation the Ethics of Artificial Intelligence Итоговый документ. Первый проект рекомендации об этических аспектах искусственного интеллекта SHS/BIO/AHEG-AI/2020/4 REV.2 URL:https://unesdoc.unesco.org/ark:/48223/pf0000373434_rus. (Last accessed:16.01.2022).

24. European ethical Charter on the use of Artificial Intelligence in judicial systems and their environment. URL:https://www.coe.int/en/web/cepej/cepej-european-ethical-charter-on-the-use-ofartificial-intelligence-ai-in-judicial-systems-and-their-environment (Last accessed:16.01.2022).

25. Klimenko, K.O. (2021). Suchasni informacijni instrumenti v sudovij ta advokats'kij dijal'nosti [Modern information tools in court and advocacy]. Naukovij visnik Uzhgorods'kogo Nacional'nogo Universitetu. Serija: Pravo - Scientific Bulletin of Uzhhorod National University. Series: Right, 65, 348-352 [in Ukrainian]. 
26. U Kitaï vpershe proveli sudove zasidannja, na jakomu funkciju suddi vikonuvav ShI [A court hearing was held in China for the first time, at which AI served as a judge].www.everest.ua Retrived from https://www.everest.ua/u-kytayi-vpershe-provely-sudove-zasidannya-na-yakomufunkcziyu-suddi-vykonuvav-shi/ [in Ukrainian].

27. «More than 97\% accuracy»: Chinese scientists develop AI «prosecutor». URL:http://www.koreatimes.co.kr/www/world/2021/12/672_321168.html. (дата звернення 10.01.2022).

28. Urjad Estoniï zvernuvsja do IT-specialista dlja stvorennja robota-suddi [The Estonian Government has approached an IT specialist to set up a robot judg].legalhub.online Retrived from https://legalhub.online/legal-tech/uryad-estoniyi-zvernuvsya-do-it-spetsialista-dlya-stvorennyarobota-suddi/ [in Ukrainian].

29. Rishennja Radi suddiv Ukraïni "Pro pogodzhennja Koncepciï pobudovi Edinoï sudovoï informacijno-telekomunikacijnoï sistemi" [Decision of the Council of Judges of Ukraine "On approval of the Concept of building the Unified Judicial Information and Telecommunication System"]. (n.d). zakon.rada.gov.ua Retrived from: https://zakon.rada.gov.ua/rada/show/v0097414-19\#n9 [in Ukrainian].

30. V ukraïns'kih sudah vikoristovuvatimut' shtuchnij intelekt: gromads'ka media-platforma. [Artificial intelligence will be used in Ukrainian courts: a public media platform].tmcinfo.com.ua Retrived from: $\quad$ https://tmcinfo.com.ua/publications/2021/02/14/v-ukrajinskyh-sudah-vykorystovuvatymutshtuchnyj-inte [in Ukrainian].

31. Shishka, N. V. (2021). Shtuchnij intelekt v ukraïns'komu pravosuddi: pravovi peredumovi zaprovadzhennja [Artificial intelligence in Ukrainian justice: legal prerequisites for implementation]. Juridichnij naukovij elektronnij zhurnal - Legal scientific electronic journal, 3, 143-145 [in Ukrainian]. 